\title{
Human papillomavirus and schistosomiasis associated bladder cancer
}

\author{
K Cooper, Z Haffajee, L Taylor
}

\begin{abstract}
Aims-To determine the human papillomavirus DNA status of schistosomal associated squamous cell carcinoma of the urinary bladder in South Africa.

Methods-Twenty five archival samples of bladder squamous cell carcinoma associated with Schistosoma haematobium were subjected to non-isotopic in situ hybridisation and the polymerase chain reaction for the detection of human papillomavirus $6,11,16,18,31$, and 33 genotypes.

Results-Using these two techniques, none of the 25 cases was shown to harbour human papillomavirus DNA.

Conclusions-This study abrogates the role of human papillomavirus in schistosoma associated bladder carcinoma in South Africa. It is suggested that other factors including nitrosamine exposure, p53 mutation, and additional unknown chromosomal events play a major role in the development of this parasite associated neoplasm.

(F Clin Pathol: Mol Pathol 1997;50:145-148)
\end{abstract}

Keywords: Schistosoma haematobium; urinary bladder; squamous cell carcinoma; human papillomavirus

In Africa, schistosomiasis associated bladder cancer in Africa tends to present as squamous cell carcinomas in relatively young individuals. ${ }^{1}$ This association is clearly defined with Schistosoma haematobium, the causative agent of urinary or bladder schistosomiasis. In a previous study in South Africa, p53 mutations were recorded in $57 \%$ of schistosomal associated squamous cell carcinomas of the urinary bladder. The majority was detected in exon 8 with multiple mutations, a fact that is suggestive of the involvement of a carcinogenic agent. ${ }^{2}$

The association of human papillomavirus (HPV) and non-schistosomal bladder squamous cell cancers has been reported in isolated cases in the USA. ${ }^{34}$ The first case occurred in a 61 year old female who was immunocompetent and had previous evidence of papillomavirus associated disease. ${ }^{3}$ The second was a renal transplant recipient on chronic immunosuppression. ${ }^{4}$ A recent Egyptian study has also demonstrated HPV DNA in six of 16 $(38 \%)$ bladder squamous cell cancers. ${ }^{5}$ In addition, the majority of the HPV positive cases in this study harboured schistosomiasis.

The present study was undertaken to investigate a possible association between HPV and schistosomiasis in squamous cell cancers of the urinary bladder in South Africa and to correlate this with the previous demonstration of p53 mutational analysis. ${ }^{2}$ In addition, a multistep carcinogenetic pathway for schistosomal associated bladder squamous cell carcinoma is proposed.

\section{Methods and materials}

TISSUE SAMPLES

Twenty five paraffin wax embedded tissue samples of bladder carcinomas from individuals infected with $S$ haematobium were obtained from the departmental archives. All tumours were reviewed and classified as invasive squamous cell carcinomas, closely associated with ova of $S$ haematobium.

NON-ISOTOPIC IN SITU HYBRIDISATION

Non-isotopic in situ hybridisation (NISH) was performed using a technique described previously. ${ }^{6} 7$ Sections $(4 \mu \mathrm{m})$ from the paraffin wax embedded tissue samples were cut on to slides pretreated with aminopropyltriethoxysilane (Sigma, St Louis, Missouri, USA). The sections were allowed to dry overnight at $42^{\circ} \mathrm{C}$ and then dewaxed and rehydrated according to standard protocols. The slides were treated with $3 \%$ hydrogen peroxide in methanol to reduce residual non-specific peroxidase activity. Unmasking of nucleic acids was achieved by a limited proteolysis in proteinase $\mathrm{K}(500 \mu \mathrm{g} / \mathrm{ml})$ at $37^{\circ} \mathrm{C}$ and the reaction stopped in distilled water after 15 minutes. The slides were air dried prior to the addition of aliquots of hybridisation mix $(6 \mu \mathrm{l})$ containing $2 \mathrm{ng} / \mu \mathrm{l}$ of digoxigenin labelled HPV $6,11,16$, 18,31 , or 33 (a gift from Professor JO'D McGee, Oxford, UK). Each section was covered with a coverslip to prevent drying. The slides were then placed in a moist Petri dish. Target DNA and probe were denatured in a hot air oven at $95^{\circ} \mathrm{C}$ for 15 minutes and then allowed to hybridise at $42^{\circ} \mathrm{C}$ for two hours. The sections were then subjected to two posthybridisation washes of five minutes each in $4 \times$ standard saline citrate buffer and incubated in Tris buffered saline containing 5\% (wt/vol) bovine serum albumin and $5 \%(\mathrm{vol} / \mathrm{vol})$ Triton $\mathrm{X}-100$ (TBT) for 10 minutes.

Detection of hybridised probe followed conventional immunohistochemical techniques. Sections were incubated for 30 minutes with monoclonal anti-digoxigenin (1/10 000; Sigma) followed by biotinylated rabbit antimouse $F\left(a^{\prime}\right) 2$ fragment (1/200; Dako, Glostrup, Denmark) for 30 minutes. The final incubation was in avidin-peroxidase conjugate (1/75; Dako) containing powdered non-fat milk $(0.05 \mathrm{mg} / \mu \mathrm{l})$ as a further means of 
Table 1 PCR primer sequences for the HPV E6 gene and $\beta$ globin gene*

\begin{tabular}{llll}
\hline Name & 5' $\rightarrow 3^{\prime}$ nucleotide sequencet & Target & Strand \\
\hline WD72 & CGGTCGGGACCGAAAACGG & HPV E6 & + \\
WD76 & CGGTTSAACCGAAAMCGG & HPV E6 & + \\
WD66 & AGCATGCGGTATACTGTCTC & HPV E6 & - \\
WD67 & WGCAWATGGAWWGCYGTCTC & HPV E6 & - \\
WD154 & TCCGTGTGGTGTGTCGTCC & HPV E6 & - \\
GH20 $\ddagger$ & GAAGAGCCAAGGACAGGTAC & $\beta$ globin & + \\
PCO4 & CAACTTCATCCACGTTCACC & $\beta$ globin & -
\end{tabular}

^ Reference 8; † Degenerate code, $W=A+T ; \quad Y=C+T ; \quad S=G+C ; \quad \ddagger$ Product size 268 base pairs.

reducing non-specific nuclear staining. All dilutions of antisera were made up in TBT. Sections were incubated in diaminobenzidine (DAB) as chromogen substrate and counterstained lightly in Mayer's haematoxylin. Positive control sections obtained from paraffin embedded penile squamous cell carcinoma tissue blocks known to contain HPV 16 (by both NISH and polymerase chain reaction (PCR)) were included in each experiment. Negative controls comprised similar tissue sections and steps with the omission of HPV DNA probes.

\section{POLYMERASE CHAIN REACTION}

Two $10 \mu \mathrm{m}$ sections of tissue were cut from each specimen and placed on a clean glass slide. Proper PCR protocol was observed at all times to prevent contamination and cross contamination of samples. The sections were dewaxed and rehydrated as per standard protocol, rinsed in sterile distilled water, and allowed to air dry. DNA was extracted from the samples using the QIAGEN QIAamp tissue kit (QIAGEN Ltd, Dorking, UK). The samples were suspended in a lysis buffer containing proteinase $\mathrm{K}$ and allowed to incubate overnight at $55^{\circ} \mathrm{C}$. DNA was precipitated with ethanol in a spin column and finally eluted in water. A volume of $10 \mu \mathrm{l}$ was amplified for each DNA sample using a mixture of positive and negative strand primers to the E6 region. ${ }^{8}$ Each $50 \mu \mathrm{l}$ reaction contained $10 \mathrm{mM}$ Tris $\mathrm{HCl}, 50 \mathrm{mM}$ $\mathrm{KCl}, 4 \mathrm{mM} \mathrm{MgCl}, 200 \mu \mathrm{M}$ DNTP, $2.5 \mathrm{U}$ Taq polymerase (Boehringer Mannheim, Randburg, South Africa) and $0.1 \mu \mathrm{M}$ each of primers WD72, WD66, WD154, and $0.4 \mu \mathrm{M}$ of WD76 and WD67. The PCR primer sequences are given in table 1 , and are capable of targeting the common HPV genotypes. ${ }^{8}$ Parallel amplification of the $\beta$ globin gene $(\mathrm{GH} 20$ and PC04) was performed to determine the integrity of the DNA in each sample. Three step amplification for both HPV E6 and $\beta$ globin was performed on a Perkin Elmer thermocycler as follows: denaturation for four minutes at $94^{\circ} \mathrm{C}$ followed by 40 cycles of incubation at $95^{\circ} \mathrm{C}$ for one minute, $55^{\circ} \mathrm{C}$ for one minute, and $72^{\circ} \mathrm{C}$ for one minute This was followed by a five minute extension period at $72^{\circ} \mathrm{C}$.

Aliquots $(15 \mu \mathrm{l})$ of the amplification product were analysed for the expected product size of 240 base pairs (HPV) and 268 base pairs $(\beta$ globin) on a $3 \%$ agarose gel, and stained with ethidium bromide. The molecular weight of the products was determined by comparison with DNA molecular weight marker V (pBR 322 DNA cleaved with HaeIII; Boehringer
Mannheim). Extracted DNA from paraffin sections known to contain HPV DNA was used as a positive control. Two negative control tubes were set up using the same PCR method but sample DNA was omitted and extracted DNA from tissue without HPV was used. Gels were viewed with an ultraviolet transilluminator and photographed on Polaroid film.

\section{Results}

CLINICAL DETAILS

Haematoxylin and eosin sections of all 25 tumours were reviewed and classified as squamous cell carcinomas. Invasive islands of tumour tissue were closely associated with schistosomal ova within the stroma in all cases. कै The age of the patients ranged from $29-72 \vec{\circ}$ years (18 males and seven females), the median age being 47 years. This is similar to that $\omega_{0}$ reported in the literature, ${ }^{1}$ with the majority of patients with schistosomal associated bladder cancer being younger than 50 .

NON-ISOTOPIC IN SITU HYBRIDISATION

None of the 25 cases harboured within nuclei of squamous cell carcinomas. Positive and negative control sections on tissue $\bar{c}$ with and without HPV DNA demonstrated $\frac{\bar{D}}{\mathbb{D}}$ positive and negative NISH signals, respectively.

POLYMERASE CHAIN REACTION

Amplimers of the HPV E6 gene (240 base pairs) were not present in any of the 25 tumours, even though intact DNA was demon- $\frac{}{D}$ strated in all cases with the amplification of the $\beta$ globin gene (268 base pairs). Both positive 윽 and negative controls produced expected results with respect to HPV DNA and $\beta$ globin gene amplification (that is, positive and negative, respectively).

\section{Discussion}

The association between urinary schistosomia- $\delta$ sis and squamous cell carcinoma of the bladder in Africa is well established. Epidemiological 윽 studies have demonstrated clearly that there is $\frac{7}{0}$ a high incidence of bladder carcinoma in endemic areas of urinary schistosomiasis. The $N$ majority of these cancers tend to be squamous $N$ cell carcinoma in young individuals and are N associated with a heavy schistosomal egg load. ${ }^{1} \mathrm{~W}$ A persistent secondary bacterial infection in schistosomal bladders has also been demon- $\frac{C}{D}$ strated. Organisms, such as Escherichia coli and $\stackrel{\oplus}{\rightarrow}$ Proteus spp, capable of reducing nitrates to 0 nitrites with formation of $\mathrm{N}$-nitrosamines have $\stackrel{\circ}{\circ}$ been the focus of attention. ${ }^{9}{ }^{10}$ However, bacte- $\stackrel{ }{\triangle}$ rial nitrate reductase is not the only enzyme $\stackrel{\mathbb{Q}}{\varrho}$ implicated in schistosomal associated bladder $\overline{2}$ carcinogenesis. Production of carcinogenic 8 metabolites from tryptophan and elevated응 levels of the deconjugating enzyme glucuronidase $^{11}$ have also been cited as cofactors. ${ }^{12}$ An important animal study has shown that baboons infected with $S$ haematobium and then fed with the N-nitroso compound, BBN, developed bladder tumours. ${ }^{13}$ However, uninfected control baboons fed on BBN did not develop tumours more than two 
Table 2 Prevalence of human papillomavirus (HPV) in bladder transitional cell carcinoma (TCC) in several countries

\begin{tabular}{lll}
\hline Country & $\%$ HPV in TCC & Reference \\
\hline USA (Philadelphia) & $20(4 / 20)$ & Shibutani et al, $1992^{20}$ \\
USA (Texas) & $0(0 / 33)$ & Saltzstein et al, $1993^{21}$ \\
Canada (Quebec) & $39(28 / 71)$ & LaRue et al, $1995^{22}$ \\
UK (Wales) & $16(12 / 76)$ & Bryant et al, $1991^{23}$ \\
UK (Surrey) & $0(0 / 100)$ & Knowles, $1992^{24}$ \\
Sweden (Uppsala) & $2(1 / 44)$ & Chetsanga et al, $1992^{25}$ \\
Japan (Fukui) & $81(39 / 48)$ & Anwar et al, $1992^{26}$ \\
Japan (Kochi) & $31(28 / 90)$ & Furihata et al, $1993^{27}$ \\
Spain (Cordoba) & $9(7 / 76)$ & Lopez-Beltran, Munoz, $1995^{28}$ \\
\hline
\end{tabular}

years after exposure. In contrast, baboons infected with $S$ haematobium, but not receiving $\mathrm{BBN}$, developed schistosomal hyperplastic polyps only. This evidence suggests that bladder schistosomiasis provides the proliferative stimulus to a carcinogen exposed (nitrosoamine) epithelium.

In a recent study, p53 mutations were demonstrated in $\sim 57 \%$ of schistosomal associated bladder squamous cell carcinomas. ${ }^{2}$ The majority of these mutations was detected in exons 7 and 8, and they included both double and triple mutational events. This is similar to the multiple mutations found in rat kidney and oesophageal tumours following exposure to alkylating N-nitroso compounds. ${ }^{14}$ Furthermore, the preponderance of $\mathrm{G}$ to $\mathrm{A}$ transitions in the schistosomal cases ${ }^{2}$ harbouring multiple mutations is characteristic of the molecular changes elicited by the action of alkylating $\mathrm{N}$-nitroso compounds. Although a single base mutational hotspot in p53, similar to that demonstrated in aflatoxin exposed hepatocellular carcinoma, ${ }^{15}{ }^{16}$ was not identified in schistosomal bladder cancers, nevertheless, it is significant that the p53 mutations in schistosomal bladder cancers are limited mainly to exons 7 and 8 , with multiple mutations being a common feature.

Inactivational events associated with the p53 tumour suppressor gene are the most common molecular changes recorded in bladder transitional cell carcinoma. ${ }^{17} 18$ Genetic changes associated with this locus are generally considered to be late events, possibly linked to transition from a low grade to a high grade transitional cell carcinoma. ${ }^{19}$ In view of the evidence presented above, p53 mutational events would be unlikely to occur as late events in schistosomal bladder cancers, as nitrosamine exposure occurs in tandem with urinary schistosomiasis and chronic bacteriuria. Hence, it is proposed that p53 mutational events in schistosomal bladder squamous cell carcinoma probably occur early on in bladder carcinogenesis.

The role of HPV in transitional cell carcinoma of the bladder is a subject of controversy. Studies investigating the presence of HPV in bladder transitional cell carcinoma have varied not only between continents, but also within countries $^{20-28}$ (table 2). The Japanese studies, however, have demonstrated a strong association between HPV and bladder transitional cell carcinoma. ${ }^{26}{ }^{27}$ The majority of HPV positive transitional cell carcinomas harboured high risk oncogenic HPV types such as HPV 16,18 , or $33^{22}{ }^{26-28}$ Furthermore, multiple infections involving oncogenic HPV types were present, especially in the Japanese series. ${ }^{26}{ }^{27} \mathrm{~A}$ recent study from Egypt demonstrated HPV DNA in six of $16(38 \%)$ bladder squamous cell cancers, the majority of which was associated with schistosomiasis. ${ }^{5} \mathrm{HPV}$ types 16 or 18 were present in the majority of these tumours. However, the present study failed to demonstrate HPV in schistosomal associated squamous cell cancers of the bladder; this discrepancy may be related to geographical differences, as has been described for bladder transitional cell carcinoma. Although HPV has been shown to be associated with uterine cervical and oesophageal cancer in South Africa, ${ }^{29}{ }^{30}$ the present study did not demonstrate the virus in schistosomal associated bladder cancer in this country. Hence, an alternative pathway for schistosomal associated bladder squamous cell carcinoma is proposed. Further molecular investigation is necessary to elucidate the later carcinogenetic events of this unique association.

The authors are grateful to Molly Long for assistance with the manuscript preparation. This study was funded with grants received from the South African Institute for Medical Research, Cancer Association of South Africa, and the Medical Research Council.

1 Lemmer LB, Fripp PJ. Schistosomiasis and malignancy. $S$ Afr Med F 1994;84:211-15.

2 Ramchurren N, Cooper K, Summerhayes IC. Molecular events underlying schistosomiasis-related bladder cancer. Int $\mathcal{F}$ Cancer 1995;62:237-44.

3 Kerley SW, Persons DL, Fishback JL. Human papillomavirus and carcinoma of the urinary bladder. Mod Patho 1991;4:316-19.

4 Maloney KE, Wiener JS, Walther PH. Oncogenic human papillomaviruses are rarely associated with squamous cell carcinoma of the bladder: evaluation by differential polymerase chain reaction. $f$ Urol 1994;151:360-4.

5 Zekri A-RN, El-Kabany M, Khaled HM. Concordance between PCR amplifiable HPV DNA and the presence of inclusion bodies in bilharzial bladder cancer among Egyptians. Cancer Mol Biol 1995;2:441-7.

6 Cooper K, Herrington CS, Graham AK, Evans MF, McGee JO'D. In situ human papillomavirus (HPV) genotyping of cervical intraepithelial neoplasia in South African and British patients: evidence for putative HPV integration in vivo. 7 Clin Pathol 1991;44:400-5.

7 Grayson W, Taylor L, Cooper K. Detection of integrated high risk human papillomavirus in adenoid cystic carcinoma of the uterine cervix. $\mathcal{F}$ Clin Pathol 1996;49:1-5.

8 Bauer HM, Greer CE, Manos MM. Determination of genital papillomavirus infection by consensus polymerase chain reaction amplification. In: Herrington CS, McGee JO'D reaction amplification. In. Herrington CS, McGre J' V, eds. Diagnostic molecular pathology - a practical approach

9 El-Aaser AA, El-Merzabani MM, Higgy NA, El-Habet AE. A study on the etiological factors of bilharzial bladder can cer in Egypt. 6. The possible role of urinary bacteria. Tumori 1982;68:2324-8.

10 Hicks RM, Ismail MM, Walters CL, Beecham PT, Rabie MF, El-Alamay MA. Association of bacteriuria and urinary nitrosamine formation with Schistosoma haematobium infection in the Qualyub area of Egypt. Trans Roy Soc Trop Med Hyg 1982;76:519-28.

11 Fripp PJ. The origin of urinary-glucoronidase. $\mathrm{Br} f$ Cancer 1965;19:330-5.

12 Tricker AR, Mostafa MH, Spiegelhalder B, Preussman R. Urinary excretion of nitrate, nitrite and N-nitroso compounds in schistosomiasis and bilharzia-bladder-cance patients. Carcinogenesis 1989;10:547-52.

13 Hicks RM, James C, Webbe G. Effect of Schistosoma haematobium and N-butyl-N-(4-hydroxybutyl) nitrosamine on the development of urothelial neoplasia in the baboon. Br $\mathcal{F}$ Cancer 1980;42:730-55.

14 Ohgaki H, Hard EC, Hirota N, Maekawa A, Takahashi M, Kleihues P. Selective mutations of codon 204 and 213 of the 53 gene in rat tumors induced by alkylating N-nitroso compounds. Cancer Res 1992;52:2995-8.

15 Bressac B, Kew M, Wands J, Ozturk M. Selective G-to-T mutations of p53 in hepatocellular carcinoma from southmutations of p53 in hepatocellular carcinoma

16 Hsu IC, Metcalf RA, Sun T, Welsh JA, Wang NJ, Harris CC. Mutational hotspot in the $\mathrm{p} 53$ gene in human hepatocellular carcinomas. Nature (London) 1991;350:427-8.

17 Sidransky D, Von Eschenbach A, Tsai YC, Jones P, Summerhayes I, Marshall F, et al. Identification of p53-gene mutations in bladder cancers and urine samples. Science 1991;252:706-9. 
18 Fujimoto K, Yamada Y, Okajima E, Kakizoe T, Sasaki H, Sugimura $\mathrm{T}$, et al. Frequent association of p 53 gene mutations in invasive bladder cancer. Cancer Res 1992;52 1393-8.

19 Olumi AF, Tsai YC, Nichols PW, Skinner DG, Cain DR, Bender LI, et al. Allelic loss of chromosome 17p distinguishes high-grade from low-grade transitional-cell carcinomas of the bladder. Cancer Res 1990;50:7081-3.

20 Shibutani YF, Schoenberg MP, Carpiniello VL, Malloy TR. Human papillomavirus associated with bladder cancer. Human papillomaviru
Urology 1992;40:15-7.

21 Saltzstein DR, Orihuela E, Kocurek JN, Payne DA, Chan TS, Tyring SK. Failure of the polymerase chain reaction to detect human papilloma virus in transitional cell carcinoma of the bladder. Anticancer Res 1993;13:423-6.

22 LaRue $\mathrm{H}$, Simoneau M, Fradet Y. Human papillomavirus in transitional cell carcinoma of the urinary bladder. Clin Cancer Res 1995;1:435-40.

23 Bryant P, Davies P, Wilson D. Detection of human papillomavirus DNA in cancer of the urinary bladder by in situ mavirus DNA in cancer of the urinary
hybridization. Br $\mathcal{A}$ Urol 1991;68:49-52.

24 Knowles MA. Human papillomavirus sequences are not detectable by Southern blotting or general primermediated polymerase chain reaction in transitional cel tumours of the bladder. Urol Res 1992;20:297-301.
25 Chetsanga C, Malmstrom PU, Gyllenstein U, MorenoLopez J, Dinter Z, Pettersson U. Low incidence of human papillomavirus type 16 DNA in bladder tumor detected by the polymerase chain reaction. Cancer 1992;69:1208-11.

26 Anwar K, Naiki H, Nakakuki K, Inuzuka M. High frequency of human papillomavirus infection in carcinoma of the urinary bladder. Cancer 1992;70:1967-73.

27 Furihata $M$, Inque $\mathrm{K}$, Ohtsuki $\mathrm{Y}$, Hashimoto $\mathrm{H}$, Terao $\mathrm{N}$, Fujita Y. High-risk human papillomavirus infections and overexpression of $\mathrm{p} 53$ protein as prognostic indicators in transitional cell carcinoma of the urinary bladder. Cancer Res 1993;53:4823-7.

28 Lopez-Beltran A, Munoz E. Transitional cell carcinoma of the bladder: low incidence of human papillomavirus DNA detected by the polymerase chain reaction and in situ hybridization. Histopathology 1995;26:565-9.

29 Cooper K, Herrington CS, Graham AK, Evans MF, McGe JO'D. In situ evidence for HPV 16, 18, 33 integration in cervical squamous cell cancer in Britain and South Africa f Clin Pathol 1991;44:406-9.

30 Cooper K, Taylor L, Govind S. Human papillomavirus DNA in oesophageal cancer in South Africa. F Pathol 1995; 175:273-7. 